\title{
QUALITY TRAITS OF CARCASS SIDES AND MEAT OF MORAVKA AND MANGALITSA PIG BREEDS
}

\author{
M. Petrović ${ }^{1}$, Č. Radović ${ }^{2}$ N. Parunović ${ }^{3}$, M. Mijatović ${ }^{1}$, D. \\ Radojković $^{1}$, S. Aleksić ${ }^{2}$ N. Stanišićc ${ }^{2}$ M. Popovac ${ }^{1}$ \\ ${ }^{1}$ Faculty of Agriculture, 11080, Belgrade - Zemun, Republic of Serbia \\ ${ }^{2}$ Institute for Animal Husbandry, 11080, Belgrade-Zemun, Republic of Serbia \\ ${ }^{3}$ Institute of Meat Hygiene and Technology, 11000, Belgrade, Republic of Serbia \\ Corresponding author:milica@agrif.bg.ac.rs \\ Original scientific paper
}

Abstract: Objective of this paper was to evaluate phenotypic variability of carcass side traits and quality of meat of fatteners (male castrated heads) of Moravka breed (M) and Mangalitsa (swallow-belly Mangalitsa - LM). The quantity and content of meat were determined based on dissection of left carcass sides (Walstra and Merkus, 1996). Also, nutritive properties of musculus longissimus dorsi (m.l.d.) were established. Obtained data were processed using GLM procedure of the program package SAS 9.1.3 (SAS Inst.Inc., 2002-2003). Results of the study show that Moravka fatteners had longer carcass sides $(+6.82$ and $+5.00 \mathrm{~cm}$ ) compared to Mangalitsa breed, corrected to average body weight at slaughtering. Fatteners of $\mathrm{M}$ breed had in average higher total mass of back-loin part $(+0.685, \mathrm{P}<0.05)$ and average quantity of muscles in the same part of carcass side $(+0.631 \mathrm{~kg}, \mathrm{P}<0.01)$, compared to fatteners of LM breed. Also, they had higher quantity of muscle in belly-rib part $(+0.237 \mathrm{~kg}, \mathrm{P}<0.05)$ compared to LM. Share of muscle tissue in back-loin and belly-rib carcass side parts corrected for WCC, was higher in $\mathrm{M}$ carcass sides than in LM $(\mathrm{P}<0.01)$. Conversely, muscle tissue content in shoulders of Mangalitsa was higher $(+4.8 \% ; \mathrm{P}<0.05)$ than in Moravka. Share of muscle tissue in carcass sides of M pigs was by $4.3 \%$ higher compared to LM carcass sides. In m.l.d. of Moravka water content was higher $(+6.1 \%, \mathrm{P}<0.01)$, content of total lipids $(-6.5 \%, \mathrm{P}<0.05)$ and cholesterol $(-19.68$ $\mathrm{mg} / 100 \mathrm{~g}, \mathrm{P}<0.001)$ was lower than in Mangalitsa.

Key words: pig, native autochthonous breed, Moravka, Mangalitsa, carcass, meat quality

\section{Introduction}

In Republic of Serbia three native autochthonous pig breeds are registered: Mangalitsa, Moravka and Resavka. First one is the most present and the last one 
the least. Recently, the interest for native autochthonous breeds has increased not only for the purpose of gene preservation but also production of meat products manufactured in traditional way.

Mangalitsa is typical fat breed, i.e. in carcass sides there is $65-70 \%$ of fat and approx. 30-35\% of meat (Egerszegi et al., 2003). Results of recent studies (Szabó, 2001, 2002 - cit. Egerszegi et al., 2003) show that there is less than 40\% of lean meat in carcass sides, but this is enough for production of high quality ham.

Moravka is breed of combined production abilities and with more meat in carcass sides and significantly less fat (Petrović et al., 2007, 2007a, 2009).

Objective of this study was to evaluate phenotypic variability of the quality of pig carcass sides and meat of Moravka and Mangalitsa breed fatteners.

\section{Materials and Methods}

According to the objective, study included animals of Moravka (M) breed and swallow-belly strain of Mangalitsa (LM). Total of 20 heads were slaughtered (10 animals in each group) of same sex (castrated males). Traditional technology of rearing and nutrition were applied with moderate investments, which is characteristic for rearing of these native autochthonous pig breeds. Animals were slaughtered in two slaughterhouses. Linear measures of warm carcass sides were taken on slaughter line. Samples of musculus longissimus dorsi (m.l.d.) were taken to determine the chemical composition of the meat. Analytical measuring and establishing of cholesterol content was done in reference laboratory of the Institute of Meat hygiene and Technology in Belgrade. Dissection of left carcass sides was done according to EU reference method (Walstra and Merkus, 1996).

Obtained data was processed using procedure GLM of the program package "SAS/STAT"(SAS Inst.Inc., 2002-2003). In completely random model breed of fatteners and body weight at the end of fattening or mass of cooled carcass sides were included as regression effect (continuous variable) depending on the trait being analyzed.

\section{Results and Discussion}

Average body weight of animals at slaughtering was $101.22 \mathrm{~kg}$ and no statistically significant variation between breeds was observed. However, significant differences in average masses of carcass sides were established (warm and cooled carcass sides) between breeds. Average mass of cooled carcass side of M breed was higher $(84.15 \mathrm{~kg})$ compared to LM $(73.90 \mathrm{~kg})$.

Mean values of linear measures of warm carcass sides and significance of factors included in the model are presented in Table 1. Back fat thickness measured on different positions didn't vary between M and LM breeds. Research results 
show that fatteners of Moravka breed had longer carcass sides $(+6.82$ and +5.00 $\mathrm{cm})$ compared to Mangalitsa breed corrected for body weight at slaughtering. Established differences of mean values were statistically significant at the level of $\mathrm{P}<0.001$.

With the increase of BW of fatteners at slaughtering, BFW, BFCB and BFRI (from 0.48 to $0.52 \mathrm{~mm} / \mathrm{kg}$ ) and carcass side length $(0.19$ and $0.17 \mathrm{~cm} / \mathrm{kg}$ ) increased also, statistically significantly.

Table 1. Linear measures of warm carcass of Moravka and Mangalitsa breeds

\begin{tabular}{|l|c|c|c|c|c|c|}
\hline \multirow{2}{*}{ Trait $^{1}$} & \multicolumn{2}{|c|}{ LSMEAN } & \multicolumn{3}{c|}{ Level of significance for factors $^{2}$} \\
\cline { 2 - 7 } & $\begin{array}{c}\text { Moravka } \\
\text { M }\end{array}$ & $\begin{array}{c}\text { Mangalitsa } \\
\text { LM }\end{array}$ & M & B & BW & $\mathrm{R}^{2}$ \\
\hline BFW, mm & 63.15 & 61.85 & $*^{3}$ & n.s. & $* *$ & 0.37 \\
\hline BFCB, mm & 43.22 & 43.78 & $* *$ & n.s. & $* *$ & 0.46 \\
\hline BFRI, mm & 59.82 & 58.46 & $* *$ & n.s. & $* *$ & 0.42 \\
\hline BFRII, mm & 51.46 & 51.94 & n.s. & n.s. & n.s. & 0.18 \\
\hline BFRIII, mm & 59.29 & 57.71 & n.s. & n.s. & n.s. & 0.23 \\
\hline OP-A, cm & $95.56^{\mathrm{C}}$ & $88.74^{\mathrm{D}}$ & $* * *$ & $* * *$ & $* *$ & 0.82 \\
\hline OP-FR, cm & $77.80^{\mathrm{C}}$ & $72.80^{\mathrm{D}}$ & $* * *$ & $* * *$ & $* * *$ & 0.84 \\
\hline
\end{tabular}

BFW - withers back fat thickness; BFC - back fat thickness, centre back; BFR - rump back fat thickness, three position measures (BFRI, BFRII and BFRIII); carcass length: OP-A: os pubis-atlas; OP-1R: os pubis-1st rib;

${ }_{3}^{2} \mathrm{M}$ - Model; B-Breed; BW- Body weight ;

3 n.s. $\mathrm{P}>0.05 ; * \mathrm{P}<0.05 ; * * \mathrm{P}<0.01 ; * * * \mathrm{P}<0.001$;

$\mathrm{C}, \mathrm{D}$ significant at level $\mathrm{P}<0.001$

Varying of total mass of four major carcass side parts prior to dissection and quantity of muscle tissue in them are presented in Table 2.

Table 2. Total mass (TM) and quantity of muscle tissue (MT) in four parts of pig carcasses (kg)

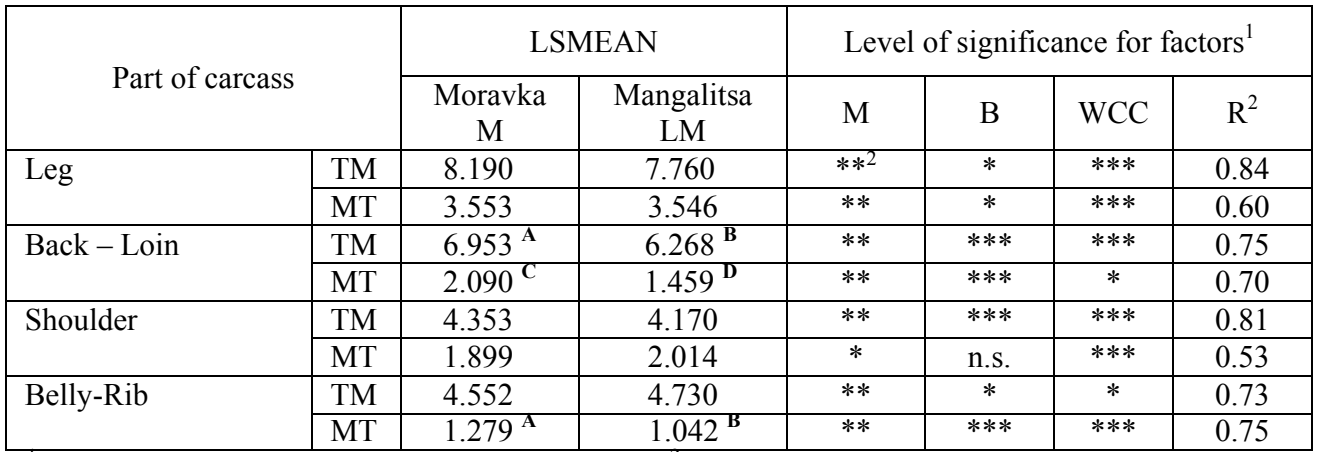

${ }^{1}$ M-Model; B - Breed, WCC-Weight cold carcass, ${ }^{2}{ }^{2 . s .} \mathrm{P}>0.05,{ }^{*} \mathrm{P}<0.05,{ }^{* *} \mathrm{P}<0.01,{ }^{* * *} \mathrm{P}<0.001$

A,B significant at level $\mathrm{P}<0.05$

C,D significant at level $\mathrm{P}<0.001$ 
Total mass of each of four major carcass side parts prior to dissection, depended on the mass of cooled carcass sides. Also, total quantity of muscle tissue in each of the four major carcass sides depended on the mass of cooled carcass sides. Quantity of muscle tissue increased from 0.015 to $0.039 \mathrm{~kg} / \mathrm{kg}$ of cooled carcass side. Fatteners of Moravka breed had in average higher total mass of back loin part of carcass side and total mass of muscles in this part $(+0.685$ and +0.631 $\mathrm{kg})$ compared to Mangalitsa $(\mathrm{P}<0.05$ and $\mathrm{P}<0.01)$. Also, they had higher quantity of muscles in belly - rib part $(+0.237 \mathrm{~kg}, \mathrm{P}<0.05)$ compared to LM. Determination of the model $\left(\mathrm{R}^{2}\right)$ used for analysis of total mass of four major carcass side parts prior to dissection and total quantity of meat in these parts, varied from 53 to $84 \%$.

Share of muscle tissue in carcass sides of $M$ pigs was by $4.3 \%$ higher than in LM carcass sides (Table 3). Content of muscle tissue in each individual carcass side part and whole carcass side didn't depend on its mass. Share of muscle tissue in back-loin part and belly-rib part was higher in carcass sides of M pigs (7.2 and $6.6 \% ; \mathrm{P}<0.01)$ compared to LM. Conversely, content of muscle tissue in Mangalitsa pig shoulders was higher $(+4.8 \%)(\mathrm{P}<0.05)$ than in Moravka.

Table 3. Shares of muscle tissue (\%) in pig carcasses and in four parts of carcasses

\begin{tabular}{|l|c|c|c|c|}
\hline \multirow{2}{*}{$\begin{array}{l}\text { Carcass side /part of } \\
\text { carcass side }\end{array}$} & \multicolumn{2}{|c|}{ LSMEAN } & \multicolumn{2}{c|}{ Level of significance for factors ${ }^{1}$} \\
\cline { 2 - 5 } & $\begin{array}{c}\text { Moravka } \\
\text { M }\end{array}$ & $\begin{array}{c}\text { Mangalitsa } \\
\text { LM }\end{array}$ & B & WCC \\
\hline Carcass side & $32.09^{\mathbf{A}}$ & $27.81^{\mathbf{B}}$ & $*$ & n.s. \\
\hline Leg & $45.47^{\mathbf{B}}$ & 43.43 & n.s. & n.s. \\
\hline Back - Loin & $30.40^{\mathbf{a}}$ & $23.23^{\mathbf{b}}$ & $* *$ & n.s. \\
\hline Shlouder & $43.71^{\mathbf{b}}$ & $48.47^{\mathbf{a}}$ & $* *$ & n.s. \\
\hline Belly - Rib & $28.38^{\mathbf{a}}$ & $21.82^{\mathbf{b}}$ & $* *$ & n.s. \\
\hline
\end{tabular}

${ }^{1} \mathrm{~B}$ - Breed, WCC-Weight cold carcass; ${ }^{2}{ }^{\text {n.s. }} \mathrm{P}>0.05,{ }^{*} \mathrm{P}<0.05,{ }^{* *} \mathrm{P}<0.01$

A,B significant at level $\mathrm{P}<0.05$

a,b significant at level $\mathrm{P}<0.01$

Table 4. Traits of nutritive value of m.l.d. (LSMEAN)

\begin{tabular}{|l|c|c|}
\hline Trait & Moravka - M & Mangalitsa - LM \\
\hline Water, \% & $70.44^{\mathbf{a}}$ & $64.38^{\mathbf{b}}$ \\
\hline Protein,\% $\%$ & 21.61 & 21.35 \\
\hline Total fat $\%$ & $6.74^{\mathrm{B}}$ & $13.24^{\mathrm{A}}$ \\
\hline Ash, \% & 1.00 & 0.96 \\
\hline Cholesterol mg/100 g & $42.14^{\mathrm{D}}$ & $61.82^{\mathrm{C}}$ \\
\hline
\end{tabular}

A,B significant at level $\mathrm{P}<0.05$

a,b significant at level $\mathrm{P}<0.01$

C,D significant at level $\mathrm{P}<0.001$

In m.l.d. from Moravka the water content was higher $(+6.1 \%, \mathrm{P}<0.01)$ and content of total fat lower $(-6.5 \%, \mathrm{P}<0.05)$ compared to Mangalitsa (Table 4). 
Average cholesterol content in m.l.d. was $42.14 \mathrm{mg}$ in $\mathrm{M}$ and $61.82 \mathrm{mg} / 100 \mathrm{~g}$ in LM. Established difference between breeds of $19.68 \mathrm{mg}$ is statistically significant at the level of $\mathrm{P}<0.001$.

Carcass side length of Moravka pigs in this study was higher than established by Gajić et al. (1997) for same breed. However, longer carcass sides were registered by Senčić et al. (2005) in Black Slavonian breed and Petrović et al. (2007a) in Moravka breed and white strain of Mangalitsa since body weight at slaughtering was higher compared to value obtained in this study (125.06 compared to $101.22 \mathrm{~kg})$. Back fat thickness, central point in LM $(43.78 \mathrm{~mm})$ was lower compared to values stated by Gajić et al. $(1997,5.2 \mathrm{~cm})$ and Holló et al. (2003; $5.9 \mathrm{~cm})$. Moravka in our study had thinner back fat, central point (43.22 compared to $54.4 \mathrm{~mm}$ ) than stated by Gajic et al. (1997), but thicker than back fat recorded in research by Petrović et al. (2007a; $35.1 \mathrm{~mm})$.

Obtained results show that average quantity of muscle tissue in back-loin and belly-rib parts of carcass side is higher in pigs of $\mathrm{M}$ breed than LM, which is in accordance to research by Petrović et al. (2009). Moravka had more muscle tissue in carcass sides than Mangalitsa which is in accordance to research of Petrovic et al. (2009), but less than Black Slavonian breed (Senčić et al., 2005) (32.09 compared to $41.0 \%$ ). Similar are mean values of the percentage of meat in LM carcass sides in this study $(27.81 \%)$ to meatiness of white strain of Mangalitsa stated by Petrović et al. (2009, 27.81\%).

Protein content in m.l.d. of both breeds was lower than value established for the same breeds by Petrović et al. (2009). However, total fats in LM in this study were almost twice higher than values obtained by other authors (13.24 compared to $7.58 \%$ ). In researches of several authors, cholesterol content in m.l.d. - in pigs varied from 56 to $63.6 \mathrm{mg} / 100 \mathrm{~g}$ (Tu et al., 1967; Moss et al., 1983; Dorade et al., 1999; Kim et al., 2008). Cholesterol content in m.l.d. of Moravka was lower than the value obtained by mentioned authors, but in case of LM it was similar to research results obtained by the last two authors.

\section{Conclusion}

Results of this research confirmed that animals of Moravka breed have carcass of higher quality compare to Mangalitsa. Also, in m.l.d. of Moravka there was less total fats and cholesterol than in Mangalitsa. Both native autochthonous breeds, beside gene preservation and expanding of the population (especially Moravka and Resavka) are very suitable for outdoor rearing, for organic livestock production and manufacturing of traditional pork meat products. 


\section{Acknowledgment}

Research was financed by the Ministry of Science and Technological Development, Republic of Serbia, project TR 20087a.

\section{Osobine kvaliteta polutki i mesa svinja rase moravka i mangulica}

M. Petrović, Č. Radović, N. Parunović, M. Mijatović, D. Radojković, S. Aleksić, N. Stanišić, M. Popovac

\section{Rezime}

Rezultati ispitivanja pokazuju da su tovljenici rase moravka imali duže polutke od rase mangulica, korigovane na prosečnu telesnu masu pri klanju. Tovljenici rase $\mathrm{M}$ imali su prosečno veću ukupnu masu ledjno-slabinskog dela $(\mathrm{P}<0,05)$ i prosečnu količinu mišića $\mathrm{u}$ istom delu polutki $(\mathrm{P}<0,01)$, nego rase $\mathrm{LM}$. Takodje, oni su imali i veću količinu mišića u trbušno-rebarnom delu $(\mathrm{P}<0,05)$ nego LM. Udeo mišićnog tkiva u ledjno-slabinskom i trbušno-rebarnom delu korigovan na WCC, bio je veći polutkama $\mathrm{M}$ nego kod LM $(\mathrm{P}<0,01)$. Obrnuto, sadržaj mišićnog tkiva u plećkama mangulice bio je veći nego kod moravke $(\mathrm{P}<0,05)$. Udeo mišićnog tkiva u polutkama svinja $\mathrm{M}$, bio je za $4,3 \%$ veći nego u polutkama LM. U m.l.d. moravke bio je veći sadržaj vode $(\mathrm{P}<0,01)$, manji sadržaj ukupnih masti $(-6,5 \%, \mathrm{P}<0,05)$ i holesterola $(-19,68 \mathrm{mg} / 100 \mathrm{~g}, \mathrm{P}<0,001)$ nego kod mangulice.

\section{References}

EGERSZEGI I., RÁTKY J., SOLTI L., BRÜSSOW K-P. (2003): Mangalica - an indigenous swine breed from Hungary (Review). Arch. Tierz., Dummerstorf, 46, 3, 245-256.

DORADO M., MARTIN GOMEZ E.M., JIMENEZ-COLMENERO F., MASOUD T. A. (1999): Cholestrol and fat contents of spanish commercial pork cuts. Meat Science, 51, 321-323.

GAJIĆ Ž., ISAKOV V., PUŠIĆ M., MIJATOVIĆ M., MAJOR F. (1997): Genetički resursi u svinjarstvu. Savremena poljoprivreda, 46, 1-2, 229-237.

HOLLÓ G., SEGERI J., ENDER K., NUERNBERG K., WEGNER J., SEENGER J., HOLLÓ I., REPA I. (2003): Amangalica sertések húsminőségének, valamint az 
izom és aszalonna zsírsavösszetételének vizsgálata. Acta Agraria Kaposváriensis, 7, 2, 19-32.

KIM J.H., SEONG P.N., CHO S.H., PARK B.Y., HAH K.H., YU L.H., LIMD.G., HWANG I.H., KIM D.H., LEE J.M., AHN C.N. (2008): Characterization of nutritional value for twenty-one pork muscles. Asian - Australian Journal of Animal Sciences, 21, 1, 138-143.

MOSS M., HOLDEN J. M. , ONO K., CROSS R., SLOVER H., BERRY B., LANZA E., THOMPSON R., WOLF W., VANDERSLICE J., JOHNSON H., STEWART K. (1983): Nutrient composition of fresh retail pork. Journal of Food Science, 48, 1767-1771.

PETROVIĆ M., MIJATOVIĆ M., RADOJKOVIĆ D., RADOVIĆ Č., MARINKOV G., STOJANOVIĆ LJ. (2007): Genetic resources in pig breeding Moravka. Biotechnology in Animal Husbandry, 23, 1-2, 1-12.

PETROVIĆ M., MIJATOVIĆ M., RADOVIĆ Č., RADOJKOVIĆ D., JOSIPOVIĆ S. (2007a): Genetic resources in pig breeding - carcass quality traits of breeds Moravka and Mangalitsa. Biotechnology in Animal Husbandry, 23, 5-6, 421-428. PETROVIĆ M., MIJATOVIĆ M., RADOVIĆ Č., RADOJKOVIĆ D., PARUNOVIĆ N., STANIŠIĆ N. (2009): Genetic resources in pig breeding carcass and meat quality traits of Moravka and Mangalitsa breeds. $1^{\text {st }}$ Conference of the Balkan Network for the Animal Reproduction Biotechnology, Sofia, 14. SAS INST. INC (2002-2003): The SAS System for Windows, Cary, NC. SENČIĆ Đ., BUKVIĆ Ž., ANTUNOVIĆ Z., ŠPERANDA M. (2005): Slaughter quality of black Slavonian pig - endangered breed and its cross-breeds with Swedish landrace while keeping them outdoor. Poljoprivreda, 11, 1, 43-48.

WALSTRA P., MERKUS G.S. M. (1996): Procedure for assessment of the lean meat percentage as a consequence of the new EU reference dissection method in pig carcass classification. Report ID-DLO 96.014, Lelystad, 1-22.

TU C., POWRIE W.D., FENNEMA O. (1967): Free and sterified cholesterol content of animal muscles and meat products. Journal of Food Science, 32, 30-34. 